Evi Purnamawati, Kekuasaan Dewan Perwakilan Rakyat dalam Penggunaan Hak Angket Menurut Undang-Undang Dasar 1945, Halaman 303-316

\title{
KEKUASAAN DEWAN PERWAKILAN RAKYAT DALAM PENGGUNAAN HAK ANGKET MENURUT UNDANG-UNDANG DASAR 1945
}

\author{
Evi Purnamawati \\ Fakultas Hukum Universitas Palembang \\ E-mail: evipurnamawatiplg@gmail.com
}

\begin{abstract}
This study analyzes the power of the questionnaire rights of the House of Representatives of the Republic of Indonesia. The House of Representatives is a House of Representatives and holds the power to form laws. The House of Representatives has the functions of legislative and legislative oversight. This research uses research methods using the method of literature (ribarary research). Type of normative juridical research through approaching legislation and conceptual approach of the research results of the House of Representatives, which essentially has the power to form the current law, the power began to widen towards supervision and budget, actually with the oversight function of the House of Representatives $(D P R)$ towards the executive in practice the meaning of the teaching of separation of powers began to shift, the teaching of separation of powers between state institutions must not intervene with one another. In carrying out its functions the DPR has the right of Interpellation which is the right to request information from the Government in handling Government policies that have an impact on the life of society and the state. In addition, the DPR has the Right to Question, namely the Right to Investigate Government policies that are alleged to be in conflict with laws and regulations and express opinions outside the institution. Members of the DPR have the right to submit draft laws, ask questions, submit proposals and opinions, defend themselves, the right of immunity, and the right to protocol. The recommendation of this research is that the writer suggests that the DPR should make the regulation on questionnaire rights clearer especially about the process of using the questionnaire right so that there is no multi-interpretation so that violations do not occur in the process of using the inquiry right.
\end{abstract}

Keywords: House of Representatives; Right of Questionnaire

\begin{abstract}
Abstrak
Penelitian ini menganalisis kekuasaan hak angket Dewan Perwakilan Rakyat Republik Indonesia. Dewan Perwakilan Rakyat merupakan Lembaga Perwakilan Rakyat dan memegang kekuasaan membentuk undang-undang Dewan Perwakilan Rakyat memiliki fungsi legislasi, anggaran, dan pengawasan. Penelitian ini menggunakan Metode penelitian menggunakan metode kepustakaan (ribarary research). Jenis penelitian yuridis normatif melalu mendekatan perundang-undangan dan pendekatan konseptual hasil penelitian Dewan Perwakilan Rakyat yang secara hakikatnya mempunyai kekuasaan tidak hanya membentuk undang-undang, tapi juga pengawasan dan anggaran, dengan adanya fungsi pengawasan Dewan Perwakilan Rakyat (DPR) terhadap eksekutif maka secara praktik makna dari ajaran pemisahan kekuasaan mulai bergeser, maka lembaga negara tidak boleh saling mengintervensi. DPR mempunyai Hak Angket yaitu hak melakukan penyelidikan terhadap kebijakan pemerintah yang diduga bertentangan dengan peraturan perundang-undangan dan menyatakan pendapat diluar institusi. Anggota DPR mempunyai hak mengajukan rancangan undang-undang, mengajukan
\end{abstract}


Evi Purnamawati, Kekuasaan Dewan Perwakilan Rakyat dalam Penggunaan Hak Angket Menurut Undang-Undang Dasar 1945, Halaman 303-316

pertanyaan, menyampaikan usul dan pendapat, membela diri, hak imunitas, serta hak protokoler. Rekomendasi dari penelitian ini yakni hendaknya DPR membuat peraturan tentang hak angket lebih jelas terutama tentang proses mekanisme penggunaan hak angket agar tidak multi tafsir, sehingga tidak terjadi pelanggaran-pelanggaran dalam proses penggunaan hak angket.

Kata Kunci: Dewan Perwakilan Rakyat; Hak Angket

\section{PENDAHULUAN}

Indonesia merupakan Negara konstitusional (constitusional state), yaitu Negara yang dibatasi oleh konstitusi. ${ }^{1}$ Dalam 4 (empat) ciri klasik Negara hukum Eropa Kontinental yang biasa disebut rechstaat, terdapat elemen pembatasan kekuasaan sebagai salah satu ciri pokok Negara hukum. ${ }^{2}$ Oleh karena itu menurut Montesquieu dengan teori trias politika yaitu legislatif, eksekutif dan yudikatif, sehingga tidak ada lagi yang dominan dalam menajalankan pemerintahan, seperti eksekutif dalam menjalankan kebijakan setelah dipantau oleh legislatif atau di Indonesia disebut Dewan Perwakilan Rakyat (DPR).

Terdapat 3 (tiga) fungsi utama DPR, ketiga fungsi utama tersebut adalah fungsi legislatif, fungsi anggaran dan fungsi pengawasan. Pada hakikatnya ketiga fungsi DPR tersebut memiliki hubungan yang erat dan ketiga fungsi ini

1 Jimly Asshidiqie, Pengantar Ilmu Hukum Tata Negara, Cetakan kedua, Jakarta: Rajawali Press, 2010, Hlm. 251.

2 Munir Fuadi, Teori Negara Hukum, Jakarta: Refika Aditama, 2009. selalu bersentuhan dengan fungsi yang lainnya, misalnya ketiga DPR menghasilkan Undang-undang yang kemudian disetujui bersama dengan Presiden, maka DPR harus mengatakan pengawasan terhadap perlaksanaan produk Undang-undang oleh lembaga eksekutif yaitu Presiden.

Dalam menjalankan tugas-tugasnya DPR melakukan fungsinya dengan menggunakan kewenangan yang dimiliknya, di dalam Undang-undang Dasar Negara Republik Indonesia 1945 (UUD 1945) dijelaskan tentang tugas-tugas DPR, yaitu mengawasi jalannya kinerja pemerintah dengan menggunakan hak ataupun kewajibannya. ${ }^{3}$

Dalam menjalankan tugas dan fungsinya, terkait pelaksanaan fungsi pengawasan, DPR mendapatkan 3 (tiga) hak, yakni: ${ }^{4}$

3 Hans Kelsen (diterjemahkan oleh Raisul Muttaqien), Teori Umum tentang Hukum dan Negara, 2010, hlm. 200.

${ }^{4}$ Hak DPR, http://www.dpr.go.id/tentang/hak-dpr, diakses Tanggal 18 Maret 2019. 
Evi Purnamawati, Kekuasaan Dewan Perwakilan Rakyat dalam Penggunaan Hak Angket Menurut Undang-Undang Dasar 1945, Halaman 303-316

1. Hak Interpelasi, yakni hak DPR untuk meminta keterangan kepada Pemerintah mengenai kebijakan pemerintah yang penting dan strategis serta berdampak luas pada kehidupan bermasyarakat, berbangsa, dan bernegara.

2. Hak Angket yang merupakan hak DPR untuk melakukan penyelidikan terhadap pelaksanaan suatu undang-undang/kebijakan pemerintah.

3. Hak Menyatakan Pendapat, hak DPR ini dilakukan untuk menyatakan pendapat atas: adanya suatu kebijakan pemerintah atau mengenai kejadian luar biasa yang terjadi di tanah air atau di dunia internasional; tindak lanjut pelaksanaan hak interpelasi dan hak angket; atau dugaan bahwa Presiden dan/atau Wakil Presiden melakukan pelanggaran hukum baik berupa pengkhianatan terhadap negara, korupsi, penyuapan, tindak pidana berat lainnya, maupun perbuatan tercela, dan/atau Presiden dan/atau Wakil Presiden tidak lagi memenuhi syarat sebagai Presiden dan/atau Wakil Presiden

Salah satu hak yang dimiliki DPR dalam menjalankan fungsinya untuk mengawasi pemerintahan yaitu Hak Angket atau hak DPR untuk mengadakan penyelidikan terhadap kebijakan pemerintah yang penting dan strategis serta berdampak luas pada kehidupan bermasyarakat yang diduga ketentangan dengan peraturan perundang-undangan.
Dengan merujuk kepada pandangan yang dikemukakan oleh Carl J Friedrich tersebut, pola pengaturan fungsi legislatif ditentukan oleh pola hubungan antara eksekutif dan legislatif dimana hubungan itu sangat ditentukan oleh corak sistem pemerintahan, ${ }^{5}$ di dalam literatur hukum tata negara beberapa jenis sistem pemerintahan yaitu sistem pemerintahan parlementer, sistem pemerintahan semi presidensial dan sistem pemerintahan presidensial, beberapa jenis sistem pemerintahan tersebut tidak hanya mempunyai karakter yang berbeda satu sama lain, tetapi juga mengangkut pola hubungan antara lembaga negara :

1. Hubungan pertanggungjawaban;

2. Hubungan pengawasan control;

3. Hubungan untuk menjaga keseimbangan kekuasaan;

4. Hubungan kerja sama; dan

5. Hubungan kepanesehatan.

Pola hubungan dan hak pengawasan antara lembaga legislatif, dengan merujuk naskah UUD 1945 sebelum perubahan tidak memuat fungsi dan hak pengawasan legislatif. Pengawasan berarti suatu kegiatan yang ditujukan

5 Saldi Isra, Pergeseran Fungsi Legislatif Menguatnya Model Legislatif Parlementer dalam Sistem Presidensial Indonesia, Jakarta: PT Raja Grafindo Persada, 2010, hlm. 2. 
Evi Purnamawati, Kekuasaan Dewan Perwakilan Rakyat dalam Penggunaan Hak Angket Menurut Undang-Undang Dasar 1945, Halaman 303-316

untuk menjamin terlaksananya penyelenggaraan negara oleh lembaga-lembaga kenegaraan sesuai dengan hukum yang berlaku. ${ }^{6}$ Fungsi pengawasan tersebut menurut Bagir Manan biasanya dikaitkan langsung dengan materi muatan mengenai pembentukan undang-undang dan penerapan anggaran pendapatan belanja negara.

Fungsi Dewan Perwakilan Rakyat (DPR) mempunyai hak salah satunya adalah hak angket yang erat hubungannya dengan Hak DPR sebagai anggota dan kelembagaan :

Hak Angket Dewan Perwakilan Rakyat adalah sebuah hak untuk melakukan penyelidikan yang dimiliki oleh Dewan Perwakilan Rakyat (DPR) yang memutuskan bahwa pelaksanaan suatu Undang-undang dalam kebijakan pemerintah yang berkaitan dengan hak penting, strategis dan berdampak luas pada kehidupan bermasyarakat berbangsa, bernegara bertentangan dengan ketentuan peraturan perundang-undangan. ${ }^{7}$

Praktik ketatanegaraan Indonesia, hak angket jarang dilaksanakan. Dua kali dilaksanakan pada masa pemerintahan orde lama dan dua kali dilaksanakan pada masa pemerintahan orde baru.

6 Ibid

7 Ibid, hlm. 42.
Penggunaan hak angket dalam sistem presidensial saat ini menunjukan peningkatan yang signifikan. Bahkan terkesan penggunaan hak angket DPR menjadi kurang relevan yang hakikatnya sebagai sarana penunjang pengawasan dalam ruang lingkup prinsip pengawasan dan saling mengimbangi (check and balance).

Penelitian ini bertujuan untuk mengetahui, mengkaji dan menganalisis kekuasaan Dewan Perwakilan Rakyat (DPR) dalam menggunakan hak angket menurut Undang-undang Dasar 1945 (UUD 1945). Sedangkan metode penelitian ini menggunakan metode kepustakaan (ribarary research).

\section{PEMBAHASAN}

Dewan Perwakilan Rakyat yang secara hakekatnya mempunyai kekuasaan membentuk Undang-undang sekarang ini kekuasaannya mulai melebar kearah pengawasan dan anggaran, sebenarnya dengan adanya fungsi pengawasan Dewan Perwakilan Rakyat (DPR) terhadap eksekutif maka secara praktik makna dari ajaran pemisahan kekuasaan mulai bergeser, ajaran pemisahan kekuasaan maka antara lembaga negara tidak boleh saling mengintervensi, dengan adanya fungsi pengawasan Dewan Perwakilan Rakyat 
Evi Purnamawati, Kekuasaan Dewan Perwakilan Rakyat dalam Penggunaan Hak Angket Menurut Undang-Undang Dasar 1945, Halaman 303-316

(DPR) terhadap eksekutif maka itu menandakan bahwa telah terjadi campur tangan Dewan Perwakilan Rakyat (DPR) terhadap kekuasaan eksekutif munculnya fungsi pengawasan terhadap kekuasaan eksekutif tentu bukannya tanpa alasan. ${ }^{8}$

Secara historis, keberadaan hak angket bermula dari hak untuk menginvestigasi (right to investigate) dan memeriksa penyalahgunaan kewenangan, dan menghukum penyelewengan-penyelewengan dalam administrasi pemerintahan, yang kemudian disebut right to impeachment. ${ }^{9}$ Dalam perkembangannya Hak Angket Dewan Perwakilan Rakyat adalah sebuah hak untuk melakukan penyelidikan yang dimiliki oleh Dewan Perwakilan Rakyat (DPR) yang memutuskan bahwa pelaksanaan suatu undang-undang dalam kebijakan pemerintah yang berkaitan dengan hal penting, strategi yang berdampak luas

\footnotetext{
8 Hananto Widodo, Penggunaan hak angket Dewan Perwakilan Rakyat Republik Indonesia Pasca Amandemen Undang-undang 1945, Makalah pada Simposium Satu Dasawarsa Perubahan Undang-undang Dasar 1945 di Indonesia menuju negara konstitusional Universitas Pandjajaran Bandung, FH 31 Oktober - 01 November 2012, hlm. 2.

9 Abdul Rivai Ras, Wisata Demokrasi Sulsel: Memahami Makna dan Urgensi "Hak Angket"

https://kumparan.com/abdul-rivai-ras/wisata-dem okrasi-sulsel-memahami-makna-dan-urgensi-hak \begin{tabular}{l|lll}
\hline -angket-1rLRtELqH8V, & diakses Tanggal 3
\end{tabular} Agustus 2019
}

dalam kehidupan bermasyarakat, berbangsa, bernegara, bertentang dengan ketentuan

peraturan perundang-undangan. DPR adalah Lembaga Tinggi Negara di Indonesia yang secara formil dan materil mewakili rakyat Indonesia daram sistem pemerintahan negara Republik Indonesia. Ditinjau dan aspek Ketatanegaraan, DPR memiliki tugas kewenangan sebagai berikut :

a. DPR memegang kekuasaan membentuk undang - undang;

b. Setiap rancangan UUD dibahas oleh DPR dan presiden untuk mendapat persetujuan bersama;

c. DPR mempunyai fungsi legislasi, fungsi anggaran, dan fungsi pengawasan;

d. DPR mempunyai hak interpelasi, hak angket dan hak menyatakan pendapat;

e. Setiap anggota Dewan Perwakilan Rakyat mempunyai hak mengajuhkan pertanyaan, menyampaikan usul dan pendapat, serta hak imunitas;

f. Anggota DPR berhak mengajukan usul rancangan undang-undang;

g. Peraturan Pemerintah, Pengganti undang-undang harus rnendapat Persetujuan DPR dalam persidangan yang selanjutnya; 
Evi Purnamawati, Kekuasaan Dewan Perwakilan Rakyat dalam Penggunaan Hak Angket Menurut Undang-Undang Dasar 1945, Halaman 303-316

DPR sebagaimana telah disebutkan tentang tugas dan kewenangannya dalam UUD 1945 dalam rangka membatasi kekuasaan agar tindak bertindak sewenang -wenang, rakyat kemudian memilih perwakilannya untuk duduk dalam pemerintah. DPR juga mengawasi tindakan-tindakan Presiden jika Presiden melanggar aturan negara yang telah ditetapkan UUD 1945 atau MPR maka majelis ini dapat diundang untuk persidangan istimewa agar dapat meminta pertanggung jawaban Presiden.

Dalam rangka menjalankan peran DPR tersebut, DPR dilengkapi fungsi utama yaitu :

a. Fungsi Legislasi adalah fungsi membentuk undang-undang selain itu, dalam tata tertib disebutkan badan legislasi memiliki tugas merencanakan dan menyusun program serta urutan prioritas pembahasan RUU untuk satu masa keanggotaan DPR dan setiap tahun anggaran dengan menginventarisasi masukan dari anggota fraksi, komisi, DPD, dan masyarakat untuk ditetapkan menjadi keputusan Badan Legislasi.

b. Fungsi Anggaran adalah fungsi DPR bersama-sama dengan pemerintah menyusun Anggaran Pendapatan dan Belanja Negara (APBN) dan harus mendapatkan persetujuan DPRD. Kedudukan DPR dalam penetapan APBN sangat kuat karena DPR berhak menolak RAPBN yang diajukan Presiden.

c. Fungsi Pengawasan adalah fungsi untuk mengawasi pelaksanaan undang-undang yang dijalankan oleh pemerintahan khususnya pelaksanaan APBN serta pengelolaan keuangan negara dan pengawasan terhadap kebijakan pemerintah.

\section{Hubungan Hak Angket Dewan} Perwakilan Rakyat

Pada masa era reformasi, perubahan UUD 1945 oleh MPR telah berpengaruh terhadap struktur ketatanegaraan, susunan DPR serta hubungan DPR dengan lembaga lembaga negara lainnya. Filosofi dasar dari Hak Angket DPR adalah sebagai instrumen checks and balances dalam sistem demokrasi presidensial. 10 Struktur ketatanegaraan ini mengarah kepada terciptanya mekanisme check

10 Ahli KPK: Hak Angket Hanya Ditujukan bagi Lembaga Eksekutif,

https://mkri.id/index.php?page=web. Berita\&id=1 4070, diakses Tanggal 5 Mei 2019. 
Evi Purnamawati, Kekuasaan Dewan Perwakilan Rakyat dalam Penggunaan Hak Angket Menurut Undang-Undang Dasar 1945, Halaman 303-316

and balances antar lembaga negara khususnya antar tiga cabang kekuasaan yaitu eksekutif, legislatif dan yudikatif.

UUD 1945 hasil amandemen semakin menegaskan bahwa sistem pemerintahan Indonesia adalah sistem presidensial dengan menetapkan ketentuan bahwa Presiden dan Wakil Presiden dipilih langsung oleh rakyat, tidak lagi dipilih oleh MPR. Sesuai dengan kondisi tersebut Presiden bertanggung jawab apabila terbukti melakukan pelanggaran hukum berupa penghianatan terhadap negara, korupsi, penyuapan, tindak pidana lainnya, atau perbuatan tercela

Pada sisi kekuasaan legislatif, terjadi penataan kelembagaan yang ditandai dengan reposisi dan penegasan DPR sebagai pemegang kekuasaan sebagai pembentuk undang-undang serta terbentuknya lembaga baru yaitu DPR. Selain itu terdapat satu penegasan bahwa DPR adalah lembaga yang dipilih langsung oleh rakyat, tidak ada lagi anggota yang diangkat yaitu utusan golongan dan ABRI.

Dari ketiga kekuasaan tersebut, ternyata dalam tatanan implementasinya masih dijumpai berbagai macam persoalan dalam kaitannya dengan pola hubungan yang terbangun antar lembaga negara tersebut. Perubahan konstitusi yang diikuti dengan pembentukkan dan perubahan berbagai peraturan perundang-undangan adalah untuk terbentuknya perimbangan fungsi dan tugas lembaga-lembaga negara khususnya lembaga eksekutif dan legislatif, juga dimaksudkan untuk saling mengimbangi dan saling mengawasi yang bekerja bersama sistematik berdasarkan aturan - aturan yang ada.

Dengan amandemennya UUD 1945 telah terjadi pergeseran dari stigma eksekutive heavy menjadi legislative heavy. Peran DPR menjdi menonjol karena konstitusi dan peraturan perundang - undangan telah mengatur demikian DPR dapat mengoptimalkan peran dan fungsinya agar bisa lebihkuat dalam pengawasannya terhadap pemerintahan dan dapat membantu kinerja pemerintahan dalam menjalankan pemerintahannya sesuai dengan aturan.

Pasal 25 UUD 1945 hasil amandemen menentukan bahwa DPR mempunyai fungsi legislasi, anggaran dan fungsi pengawasan dalam Pasal 27 UUD 1945 hasil amandemen ini ditentukan bahwa DPR mempunyai hak interpelasi, hak angket dan hak menyatakan pendapat. Atas dasar hal tersebut diatas, hak angket dalam 
Evi Purnamawati, Kekuasaan Dewan Perwakilan Rakyat dalam Penggunaan Hak Angket Menurut Undang-Undang Dasar 1945, Halaman 303-316

hubungannya dengan DPR merupakan hak yang melekat pada DPR selaku badan legislative berdasarkan ketentuan konstitusi serta peraturan perundang-undangan yang berlaku.

Hak angket merupakan bentuk pengawasan instensif serta investigative DPR terhadap kebijakan pemerintah. Peran DPR melalui hak angket akan lebih konkrit daripada hanya sekedar menggunakan hak meminta keterangan karena di dalam hak angket terkandung unsur dimana DPR juga ikut andil mengawali proses penyelesaian suatu kasus langsung menjadi investigator dalam kasus tersebut. Dimana denga terlibatnya DPR terhadap suatu kasus, maka diharapkan upaya penyelesaian kasus ini akan semakin menemui titik terang dan mencegah terjadinya korupsi, kolusi dan nepotisme.

Dalam penjelasan mekanisme atau tata cara penggunaan hak angket sebagai bagian dari fungsi pengawasan DPR terhadap jalannya pemerintahan, dimulai dengan adanya usulan untuk mengadakan penyelidikan mengenai suatu hal atau permasalahan, yang dapat diajukan oleh sekurang-kurangnya 25 (dua puluh lima) orang anggota DPR. Usulan tersebut disampaikan secara tertulis kepada pimpinan DPR yang disertai dengan daftar nama dan tanda tangan pengusul serta nama fraksinya, dan dinyatakan dalam suatu rumusan secara jelas tentang hal yang diselidiki dengan penjelasan dan rancangan biaya.

Usul pengadaan angket diterima oleh pimpinan DPR, ketua rapat memberitahukan kepada anggota DPR tentng masuknya usul untuk mengadakan angket, yang kemudian usulan-usulan tersbeut berserta penjelasan-penjelasan dan rancangan biayanya diberikan kepada anggota. Selanjutnya pada rapat Badan Musyawarah DPR, membahas penetuan pembicaraan dalam rapat paripurna, maka pengusul berhak mengajukan perubaahn atau menariknya kembali.

Apabila jumlah tanda tangan usul untuk mengadakan angket yang belum dibicarakan dalam rapat paripurna ternyata menjadi kurang dari jumlah tersebut, maka harus diadakan penambahan tanda tangan sehingga jumlahnya mencukupi, apabila sampai dua kali masa persidangan jumlah penanda tangan tidak terpenuhi maka usul menjadi gugur. Apabila nantinya rapat paripurna menyetujui pengadaan angket maka dibentuk panitia khusus dan keputusan DPR untuk mengadakan angket. 
Evi Purnamawati, Kekuasaan Dewan Perwakilan Rakyat dalam Penggunaan Hak Angket Menurut Undang-Undang Dasar 1945, Halaman 303-316

Terhadap hasil keputusan ini, panitia khusus selanjutnya memberikan laporan tertulis secara berkala seurang kurangnya sekali sebulan kepada pimpinan DPR, kemudian laporan tersebut dibagikan kepada seluruh anggota, dan atas usul sekurang-kurangnya 25 (dua puluh lima) orang tersebut, untuk selanjutnya dibuat laporan berkala yang nantinya menjadi bahan pembicaraan dan pembahasan dalam rapat peripurna, kecuali apabila nantinya badan musyawarah akan menetukan lain.

Setelah panitia khusus menyelesaikan pekerjaannya, panitia khusus akan memberikan laporan tertulis kepada pimpinan DPR, kemudian laporan tersbeut dibagikan kepada seluruh anggota. Terhadap pengambilan keputusan tentang laporan panitia khusus tersebut akan didahului dengan laporan hasil panitia khusus dan pendapat akhir fraksi-fraksi yang berada di DPR, yang kemudian keputusan diambil tersebut kemudian akan disampaikan kepada Presdien.

Adapun beberapa faktor yang menjadikan alasan penyebab utama perbedaan dan mekanisme tersebut :

1. Usul untuk mengadakan anglet dimajukan dengan tertulis oleh sekurang-kurangnya 30 orang anggota Dewan Perwakilan Rakyat.

2. Putusan untuk mengadakan angket diambil dalam suatu rapat terbuka Dewan Perwakilan Rakyat, yang diadakan sesudah usul itu dibicarakan dalam seksi atau seksi - seksi yang bersangkutan dan keputusan itu memuat perumusan yang teliti tentang hal yang akan diselidiki.

3. Putusan selengkapnya termaksud diumumkan dengan resmi dalam berita Negara, sesuai dengan risalah Dewan Perwakilan Rakyat yang bersangkutan.

4. Semenjak pengumuman tersebut, semua warga negara Republik Indonesia dan semua Penduduk serta orang-orang lain yang berada dalam wilayah Republik Indonesia diwajibkan memenuhi panggilan panitia hak angket.

5. Saksi-saksi dan ahli-ahli datang kepada panitia angket, naik dengan suka-rela atas panggilan tertulis maupun karena dipanggil dengan perantara juru sita.

6. Jurusita pada Pengadilan Negeri menjalankan panggilan saksi-saksi atau ahli-ahli atas perintah Panitia 
Evi Purnamawati, Kekuasaan Dewan Perwakilan Rakyat dalam Penggunaan Hak Angket Menurut Undang-Undang Dasar 1945, Halaman 303-316

Angket Langsung atau atas perintah Jaksa berhubung dengan permintaan panitia Angket.

7. Panggilan saksi-saksi atau ahli-ahli disampaikan kepada orangnya sendiri atau di tempat tinggalnya, sekurang-kurangnya tujuh hari sebelum hari pemeriksaan.

8. Catatan tertulis dari keterangan-keterangan atau berita-berita yang diberikan oleh saksi atau ahli dibacakan kepada mereka atau diberikan kepadanya untuk dibacanya dan sesudahnya ditanda tangani oleh saksi atau ahli yang bersangkutan. Dalam hal saksi atau ahli tidak dapat menulis maka catatan tersebut dibubuhi cap jempol.

9. Segala pemeriksaan oleh Panita Angket dilakukan dalam rapat tertutup.

10. Anggota-anggota Panitia Angket Wajib merahasiakan keterangan-keterangan yang diperoleh dalam pemeriksaan, sampai ada keputusan lain yang diambil oleh rapat pleno tertutup Dewan perwakilan Rakyat yang diadakan khusus untuk itu.

$\begin{array}{lrr}\text { 11. Apabila Panita Angket } \\ \text { menganggap } & \text { perlu untuk }\end{array}$

mendengar orang-orang yang berdiam di luar negeri, sebagai saksi atau ahli, maka pertanyaan-pertanyaan yang diinginkan penjawabannya dapat diberitahukan dengan tertulis oleh Panitia Angket Kepada Menteri yang bersangkutan yang membantu sepenuhnya pertanyaan-pertanyaan ini dengan perantaraan Perwakilan Indonesia di luar Negeri, dan apabila pertanyaan-pertanyaan itu mengenai soal luar negeri Kepada Menteri Luar Negeri yang membantu dipenuhinya pertanyaan-pertanyaan itu dengan perantaraan Perwakilan Luar Negeri.

12. Dengan tidak mengurangi ketentuan yang tersebut maka segala keterangan yang diberikan kepada Panitia Angket tidak dapat dipergunakan sebagai bukti dalam peradilan terhadap saksi atau ahli itu sendiri yang memberikan keterangan atau terhadap orang lain.

13. Kekuasaan dan pekerjaan Panitia Angket tidak tertunda oleh penutupan sidang-sidang atau 
Evi Purnamawati, Kekuasaan Dewan Perwakilan Rakyat dalam Penggunaan Hak Angket Menurut Undang-Undang Dasar 1945, Halaman 303-316

pembubaran Dewan Perwakilan

Rakat baru menentukan lain.

14. Rapat Pleno Dewan Perwakilan rakyat menentukan jumlah biaya angket untuk satu tahun anggaran : Jumlah itu dicantumkan dalam mata anggaran belanja Dewan Perwakilan Rakyat. ${ }^{11}$

Peredaman kekuasaan Presiden diawali dengan amandemen terhadap pasal 7 UUD 1945 (perubahan kesatu), dan pergeseran fungsi Legislasi kepada DPR dalam menyempurnakan aturan dasar konstitusi tentang supermasi hukum, hak asasi manusia, otonomi dan sebagainya. Sebagaimana pendapat Y. Hartono, sebagai berikut.

"Pedoman atas kekuasan Eksekutif dapat dipahami, sebagaimana aksioma yang dikemukakan oleh Lard acton bahwa Power attend to corrupt, and absolute power corrupts absolutely. Great men are almost always badmen dilain pihak meskipun Presiden tidak lagi mempunyai kekuasaan legistasi, sebab kekuasaan tersebut sekarang berada ditangan DPR yang menyatakan DPR memegang kekuasaan membentuk undang-undang namun presiden masih

\footnotetext{
${ }^{11}$ Undang -Undang Nomor 6 Tahun 1954 tentang Penetapan Hak Angket Dewan Perwakilan Rakyat
}

mempunyai hak mengajakan rancangan undang-undang."

Namun dalam perubahan dari executive heave menjadi legislative heave banyak juga yang menyangsikan akan terjadi perubahan menjadi lebih baik, namun kenyataannya lebih terasa tidak jauh berbeda dengan zaman orde baru yang didominasi oleh eksekutif disegala aspek kekuasaan. Legislatif dengan dominasinya mulai banyak terjadi penyelewengan kekuasaan dengan banyaknya para anggota DPR yang ditangkap oleh KPK. Maka dari itu sekarang rakyat meminta DPR membuka semua kegiatannya secara transparan yang dapat dipantau langsung oleh rakyat.

Adanya amandemen terhadap UUD 1945, sangat mempengaruhi posisi dan kewenangan DPR sebagai lembaga legislatif, perubahan radikal terhadap ketentuan Pasal 5 ayat (1) dan Pasal 20 ayat (1) UUD 1945 dengan mengurangi secara signifikasi kekuasaan Presiden dalam membuat undang-undang menjadi proses politik di DPR sebagai kekuatan paling dominan dalam menerjemahkan rumusan-rumusan normative yang terdapat dalam UUD. Kini suupremasi DPR dalam proses legislasi menjadi sangat dominan karena Presiden tidak 
Evi Purnamawati, Kekuasaan Dewan Perwakilan Rakyat dalam Penggunaan Hak Angket Menurut Undang-Undang Dasar 1945, Halaman 303-316

mempunyai pilihan lain, kecuali Mahkamah Konstitusi, dan memilih mengesahkan rancangan undang-undang. ${ }^{12}$

Beberapa perubahan menempatkan DPR sebagai lembaga penentu kata putus dalam bentuk memberi persetujuan kenegaraan adalah :

1) Presiden dalam membuat perjanjian internasional yang menimbulkan akibat luas dan mendasar bagi kehidupan rakyat.

2) Peraturan pemerintah pengganti udang-undang.

3) Pengangkatan Hakim Agung.

4) Pengangkatan dan pemberhentian anggota Komisi Yudisial. ${ }^{13}$

Disamping itu masih ada agenda lain yang memerlukan pertimbangan DPR, antara lain adalah :

a. Pengangkatan Data dan Konsul.

b. Menerima penempatan duta negara lain.

c. Pemberian amnesti dan abolisi.

Kekuasaan ke tangan DPR bertambah banyak dengan adanya kewenangan untuk mengisi beberapa jabatan strategis kenegaraan, misalnya menentukan tiga dari sembilan hakim

12 Romi Librayanto, Trias Politika dalam Struktur Ketatanegaraan Indonesia, PuKAP Indonesia, 2008.

13 Thohari, Komisi Yudisial dan Referensi Peradilan, Jakarta: Elsan Lembaga Studi dan Advokat Masyarakat, 2004, hlm. 79-37.

anggota badan Pemeriksa Keuangan (KPK) disamping DPR juga menjadi lembaga yang paling menentukan dalam proses pengisian lembaga non-state lainnya (auxiliary bodies) seperti Komisi Nasional Hak Asasi Manusia, Komisi Pemilihan umum, catatan ini akan bertambah dengan adanya keharusan untuk meminta pertimbangan DPR dalam pengisian Panglima TNI, Kepala Kepolisian Negara Republik Indonesia. ${ }^{14}$

\section{PENUTUP}

Dewan Perwakilan Rakyat yang secara hakikatnya mempunyai kekuasaan tidak hanya membentuk undang-undang, tapi juga pengawasan dan anggaran, dengan adanya fungsi pengawasan Dewan Perwakilan Rakyat (DPR) terhadap eksekutif maka secara praktik makna dari ajaran pemisahan kekuasaan mulai bergeser, maka lembaga negara tidak boleh saling mengintervensi. DPR mempunyai Hak Angket yaitu hak melakukan penyelidikan terhadap kebijakan pemerintah yang diduga bertentangan dengan peraturan perundang-undangan dan menyatakan pendapat diluar institusi.

14 Jimly Asshiddiqie, Perkembangan dan Konsolidasi Lembaga Negara Pasca Reformasi, Sekretaris Jenderal Kepaniteraan Mahkamah Konstitusi RI, Jakarta, 2005, hlm. 50. 
Evi Purnamawati, Kekuasaan Dewan Perwakilan Rakyat dalam Penggunaan Hak Angket Menurut Undang-Undang Dasar 1945, Halaman 303-316

Penggunaan hak angket oleh DPR disaat pasca reformasi, yakni dalam penggunaan hak angket DPR pasca amandemen UUD 1945 lebih banyak permasalahan dan kompleks. Hal ini dikarenakan timbulnya era reformasi yang lepas dari rezim otoriter zaman orde baru, sehingga memungkinkan terjadinya kebebasan berpendapat terhadap kebijakan

pemerintah dan meningkatnya efektifitas dalam fungsi pengawasan, fungsi anggaran dan fungsi legislasi.

Rekomendasi dari penelitian ini yakni hendaknya DPR membuat peraturan tentang hak angket lebih jelas terutama tentang proses mekanisme penggunaan hak angket agar tidak multi tafsir, sehingga tidak terjadi pelanggaran-pelanggaran dalam proses penggunaan hak angket.

\section{DAFTAR PUSTAKA}

Hananto Widodo, Penggunaan Hak Angket Dewan Perwakilan Rakyat Republik Indonesia Pasca Amandemen Undang-undang 1945, Makalah pada Simposium Satu Dasawarsa Perubahan

Undang-undang Dasar 1945 di Indonesia menuju negara konstitusional Universitas
Pandjajaran Bandung, FH 31

Oktober-1 November 2012.

Hans Kelsen, General Theory Of Law

State, Russel and Russel New York, 1971 diterjemahkan oleh Raisal Muttaqien, Teori Umum tentang Hukum dan Negara, Bandung: Penerbit Nusa Media, 2010.

Jimly Asshiddiqie, Pengantar Ilmu Hukum Tata Negara, Cetakan kedua, Jakarta: Rajawali Press, 2010.

-------, Perkembangan dan Konsolidasi Lembaga Negara Pasca Reformasi, Sekretaris Jenderal Kepaniteraan Mahkamah Konstitusi RI, Jakarta, 2005.

Romi Librayanto, Trias Politika Dalam Struktur Ketatanegaraan Indonesia, Pusat Kajian Politik, Demokrasi dan Perubahan Sosial (PuKAP), Indonesia, 2008.

Munir Fuadi, Teori Negara Hukum, Jakarta: Refika Aditama, 2009.

Saldi Isra, Pergeseran Fungsi Legislatif Menguatnya Model Legislatif Parlementer dalam Sistem Presidensial Indonesia, Jakarta: PT Raja Grafindo Persada, 2010.

Thohari, Komisi Yudisial dan Referensi Peradilan, Jakarta: Elsan Lembaga 
Evi Purnamawati, Kekuasaan Dewan Perwakilan Rakyat dalam Penggunaan Hak Angket Menurut Undang-Undang Dasar 1945, Halaman 303-316

Studi dan Advokat Masyarakat, 2004.

http://www.dpr.go.id/tentang/hak-dpr,

diakses Tanggal 18 Maret 2019.

https://mkri.id/index.php?page=web.Beri

ta\&id=14070, $\quad$ diakses Tanggal 5

Mei 2019.

https://kumparan.com/abdul-rivai-ras/wi

sata-demokrasi-sulsel-memahami-m

akna-dan-urgensi-hak-angket-1rLRt

ELqH8V, diakses Tanggal 3

Agustus 2019.

Undang-Undang Dasar RI 1945

Undang-Undang Nomor 6 Tahun 1954

tentang Penetapan Hak Angket

Dewan Perwakilan Rakyat. 